\title{
Aquatic oligochaetes associated with bryophytes in an Atlantic Forest stream
}

\author{
Luciana Falci Theza Rodrigues ${ }^{1,2}$, Lucas Deziderio Santana ${ }^{1}$ \& Roberto da Gama Alves ${ }^{I}$ \\ ${ }^{1}$ Laboratório de Invertebrados Bentônicos, Departamento de Zoologia, Instituto de Ciências Biológicas, \\ Universidade Federal de Juiz de Fora - UFJF, Campus Universitário, s/n, \\ CEP 36036-900, Juiz de Fora, MG, Brasil \\ ${ }^{2}$ Corresponding author: Luciana Falci Theza Rodrigues, e-mail: biofalci@hotmail.com
}

RODRIGUES, L.F.T., SANTANA, L.D. \& ALVES, R.G. Aquatic oligochaetes associated with bryophytes in an Atlantic Forest stream. Biota Neotrop. 13(4): http:/www.biotaneotropica.org.br/v13n4/en/abstract?shortcommunication+bn01113042013

Abstract: There are few reports in the literature about the colonization of benthic macroinvertebrates on bryophytes. The aim of the present study was to analyzed the oligochaetes established on bryophytes adhered to stones in a first-order stream. The collections were carried out in an Atlantic Forest fragment area during the dry and rainy seasons. We identified 15 taxa from a total of 422 oligochaetes specimens, of which the most abundant were Pristina sp.1, Enchytraeidae and Pristina jenkinae. Unlike other habitats, where the abundance of macroinvertebrates tends to be greater in the dry season, we did not find any significant differences in the abundance, richness, composition and diversity between the two periods. The results of this study indicate that bryophytes are possible areas of refuge for oligochaetes in periods of faster water flow.

Keywords: lotic environments, preserved areas, mosses, hepatics, Naididae.

RODRIGUES, L.F.T., SANTANA, L.D. \& ALVES, R.G. Oligoquetas aquáticos associados a briófitas em um córrego de Mata Atlântica. Biota Neotrop. 13(4): http://www.biotaneotropica.org.br/v13n4/pt/abstract?shortcommunication+bn01113042013

Resumo: Existem poucos registros na literatura sobre a colonização de macroinvertebrados bentônicos em briófitas. O presente estudo teve como objetivo analisar a fauna de oligoquetas em briófitas aderidas a pedras em um córrego de primeira ordem. As coletas foram realizadas em um fragmento de Mata Atlântica durante os períodos seco e chuvoso. Foram identificados 15 taxa de um total de 422 espécimes de oligoquetas, sendo os mais abundantes Pristina sp.1, Enchytraeidae e Pristina jenkinae. Ao contrário de outros habitats, onde a abundância de macroinvertebrados tende a ser maior no período de estiagem, diferenças significativas na abundância, riqueza, composição e diversidade não foram observadas em relação aos dois períodos. Os resultados do presente estudo indicam que as briófitas são possíveis áreas de refúgio para os oligoquetas em período de maior corrente.

Palavras-chave: ambientes lóticos, áreas preservadas, musgos, hepáticas, Naididae. 


\section{Introduction}

Bryophytes are plants frequently found in lotic ecosystems associated with rocky substrates (Heino \& Korsu 2008). Their architecture allows them to retain different fractions of organic detritus (Habdija et al. 2004), providing favorable conditions for colonization by various groups of invertebrates, including the oligochaetes, especially the Enchytraeidae (Glime 2007) and Naididae (Gorni \& Alves 2007). As a result, these invertebrates can reach densities on bryophytes up to two times greater than on other substrates, such as gravel streambeds (Suren 1992, Linhart et al. 2002). Baturina $(2007,2012)$ studying Oligochaeta on various substrates in streams and reservoirs found higher densities in stones covered by bryophytes in streams.

An extensive literature exists on the presence of oligochaetes in boglands, where the dominant vegetation is composed of Sphagnum L., being Cognettia sphagnetorum (Vejdovský, 1877) and other Enchytraeidae the most abundant and important invertebrates in these habitats (Standen \& Latter 1977, Dózsa-Farkas 1990, Carrera et al. 2011). However, studies of oligochaetes living in bryophytes of running waters are relatively scarce in the literature.

The studies of Vlčková et al. (2002) and Habdija et al. (2004), for example, carried out in streams in temperate regions, although including oligochaetes in the fauna composition analyzed, only considered them at the class or family level. In Brazil, Gorni \& Alves (2007) and Rosa et al. $(2011,2013)$ report, respectively, the presence of species of Naididae, benthic invertebrates and larvae of Chironomidae (Diptera) associated with bryophytes in lotic environments in the southeastern region of the country. The aim of the present study was to identify the aquatic oligochaetes associated with the bryophytes adhered to stones in a first-order stream in southeastern Brazil.

\section{Material and Methods}

The study was carried out in the Poço D'Anta Municipal

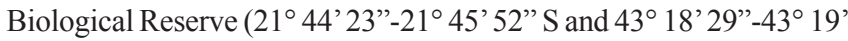
$10^{\prime \prime} \mathrm{W}$ ), a fragment of the Atlantic Forest located in the municipality of Juiz de Fora, Minas Gerais state. The specific environment studied is a shallow first-order stream whose bed is composed mainly of sand containing a large quantity of leaf litter and stones of different sizes. It is located at an altitude of $850 \mathrm{~m}$ between the coordinates $21^{\circ} 44^{\prime}$ $36 "-21^{\circ} 44^{\prime} 31^{\prime \prime} \mathrm{S}$ and $43^{\circ} 18^{\prime} 51^{\prime \prime}-43^{\circ} 18^{\prime} 53^{\prime \prime} \mathrm{W}$.

The samples were collected in the months of July, August and September 2007 (dry season) and January, February and March 2008 (rainy season). In a segment approximately $100 \mathrm{~m}$ long of the stream, each month we collected $400 \mathrm{~mL}$ of bryophytes (two pots of $200 \mathrm{~mL}$ ) adhered to different stones (1-2 cm above the water surface) by scraping with a spatula. The bryophytes were composed of two families of mosses (Pilotrichaceae Kindb. and Hypnaceae Schimp.) and one family of hepatics (Geocalycaceae H.Klinggr.).

The plant material collected was fixed in $4 \%$ formaldehyde, washed in running water using a $0.21 \mathrm{~mm}$ sieve and sorted under a stereoscopic microscope to separate the fauna. The organisms found were preserved in alcohol $70^{\circ} \mathrm{GL}$ and identified according to the taxonomic criteria adopted by Righi (1984), Brinkhurst \& Marchese (1989) and Erséus et al. (2008). The average current speed was obtained using the float method (Martinelli \& Krusche 2007). The rainfall and air temperature data were obtained from the Climatology and Environmental Analysis Laboratory of Juiz de Fora Federal University.

The faunal structure was analyzed by the abundance, richness and diversity (Shannon's index). The data were checked for homogeneity of the variances (Levene test) and normality (Shapiro-Wilk) and submitted to the T-test for significant differences between the dry and rainy seasons, using the Statistica 7 program (Statsoft 2004). To verify differences in the faunal composition between the two seasons, analysis of similarity (Anosim) was performed with the $\mathrm{R}$ program ( $\mathrm{R}$ Development Core Team 2011). Simple linear regression was used to test the relation between the dependent variables (abundance and richness) and the explanatory variable (water speed), also using the Statistica7 program. For this analysis, the data were transformed into $\log (\mathrm{x}+1)$. It is accepted $\mathrm{p}<0.05$ for all statistical tests.

\section{Results}

The average monthly rainfall was greater in the rainy season (Figure 1), causing a significant increase $(\mathrm{df}=5 ; \mathrm{Z}=2.930 ; \mathrm{p}=0.003)$ in the water speed. The air temperature, precipitation, water velocity and water depth values are reported in Table 1 .

Oligochaetes (422 specimens) belonging to the Naididae and Enchytraeidae families and the superorder Megadrili were found associated with the bryophytes (Table 2). Among the species found, the most abundant were Pristina sp.1 (29.38\%) and Pristina jenkinae (18.95\%). The Enchytraeidae accounted for $30 \%$ of the fauna.

The abundance and richness observed did not differ between the two collection periods $(\mathrm{df}=10 ; \mathrm{t}=-0.250 ; \mathrm{p}=0.807$ and $\mathrm{df}=$ $10 ; \mathrm{t}=-0.691 ; \mathrm{p}=0.505$, respectively) (Figure 2 ). There also was no difference in the composition $(\mathrm{df}=10$; Anosim $\mathrm{R}=-0.032 ; \mathrm{p}=$ $0.605)$ and diversity $(\mathrm{df}=10 ; \mathrm{t}=0.696 ; \mathrm{p}=0.501)$ of the oligochaetes fauna between the two seasons. The results of the regression analysis indicated that there was no cause and effect relationship between water velocity and abundance $\left(\mathrm{R}^{2}=0.026 ; \mathrm{F}=0.108 ; \mathrm{p}=0.758\right)$ or between water velocity and taxa richness $\left(R^{2}=0.015 ; F=0.064 ; p=\right.$ 0.812) (Figure 3).

\section{Discussion}

Unlike other stream habitats, such as submersed leaf litter, where the abundance and richness of macroinvertebrates tend to be lower in the rainy season (Kikuchi \& Uieda 2005, Silveira et al. 2006), the results of the present study appear to indicate that the bryophytes serve as areas of refuge when the current is strongest, an important condition for a group of organisms that does not have adaptations for fixation or anchorage. Besides refuge, the bryophytes normally retain periphyton and detritus that serve as food for invertebrates (Suren \& Winterbourn 1992).

In a temperate region, Percival \& Whitehead (1929) studied the fauna of macroinvertebrates in different types of substrates in streams and found that the mosses sheltered the greatest abundance of oligochaetes and that this abundance was greater in areas with slower current. On the other hand, Habdija et al. (2004) reported an increase in the density of macroinvertebrates associated with mosses with increasing water flow, besides significant differences in the composition and diversity of fauna. Baturina (2012) also found greater diversity of oligochaetes in mosses adhered to rocks in small streams with fast currents. Although the regression analysis did not

Table 1. Environmental characterization of the study area during the dry and the rainy season.

\begin{tabular}{lcc}
\hline & \multicolumn{2}{c}{ Mean and standard deviation } \\
\cline { 2 - 3 } & Dry season & Rainy season \\
\hline Air temperature $\left({ }^{\circ} \mathrm{C}\right)$ & $19.6 \pm 1.2$ & $21.93 \pm 0.30$ \\
Precipitation $(\mathrm{mm})$ & $4.33 \pm 3.07$ & $316.00 \pm 13.57$ \\
Water velocity $(\mathrm{m} / \mathrm{s})$ & $0.07 \pm 0.11$ & $0.39 \pm 0.40$ \\
Water depth $(\mathrm{cm})$ & $4.53 \pm 0.97$ & $6.73 \pm 0.75$ \\
\hline
\end{tabular}




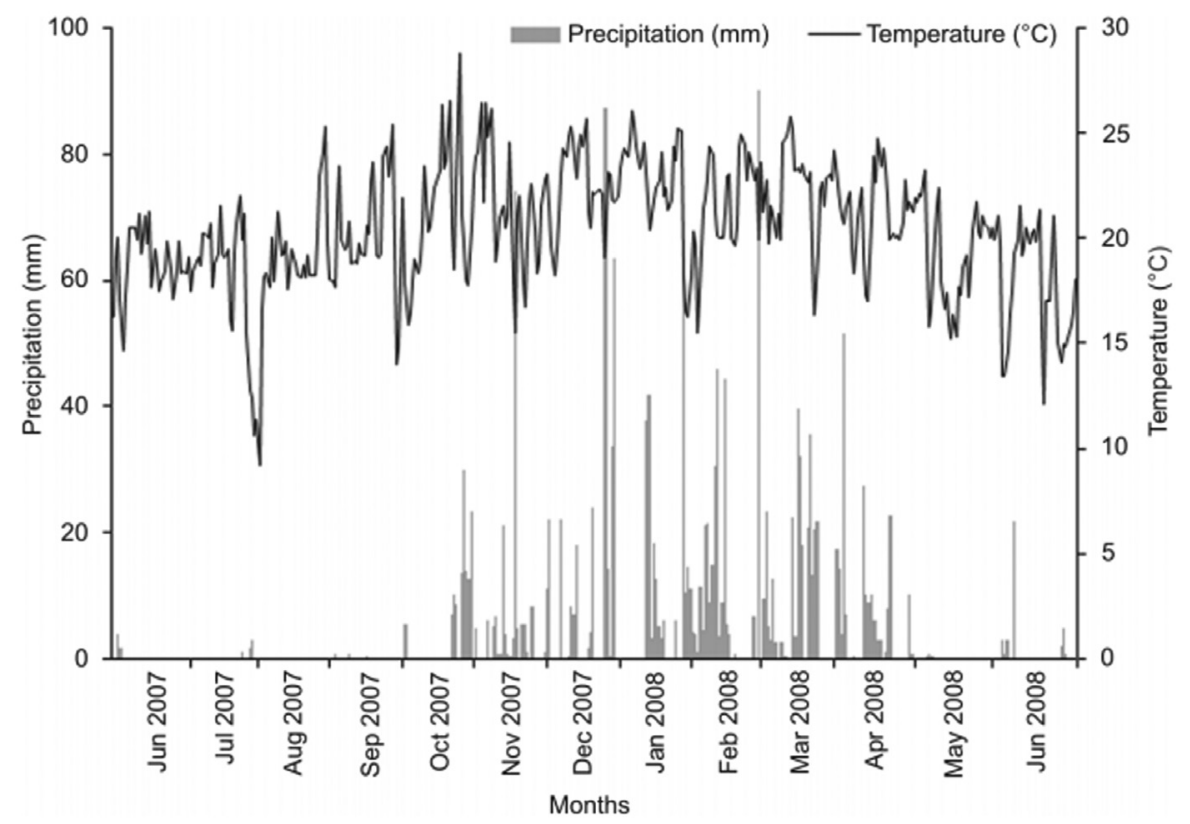

Figure 1. Monthly rainfall and average air temperature from June 2007 to June 2008 in Juiz de Fora, Brazil. The bars indicate rainfall and the lines temperature. Source: Laboratory for Climatology and Environmental Analysis, Juiz de Fora Federal University, Brazil.

Table 2. Abundance, richness and diversity of oligochaetes associated with bryophytes during the dry and the rainy season in a first-order stream in the Poço D'Anta Municipal Biological Reserve, southeastern Brazil. *The abundance values refer to the sum of the two samples collected each month.

\begin{tabular}{|c|c|c|c|c|c|c|}
\hline \multirow[t]{2}{*}{ Season } & \multicolumn{3}{|c|}{ Dry } & \multicolumn{3}{|c|}{ Rainy } \\
\hline & July* & August* & September* & January* & February* & March* \\
\hline \multicolumn{7}{|l|}{ NAIDIDAE } \\
\hline \multicolumn{7}{|l|}{ Naidinae } \\
\hline Nais communis Piguet, 1906 & 0 & 0 & 0 & 0 & 2 & 1 \\
\hline \multicolumn{7}{|l|}{ Pristininae } \\
\hline Pristina aequiseta Bourne, 1891 & 0 & 0 & 0 & 0 & 2 & 1 \\
\hline Pristina leidyi Smith, 1896 & 0 & 0 & 0 & 0 & 1 & 0 \\
\hline Pristina proboscidea Beddard, 1896 & 0 & 0 & 0 & 0 & 1 & 0 \\
\hline Pristina sima (Marcus, 1944) & 12 & 0 & 0 & 1 & 0 & 0 \\
\hline Pristina osborni (Walton, 1906) & 5 & 0 & 0 & 0 & 18 & 2 \\
\hline Pristina minuta (Stephenson, 1914) & 8 & 0 & 1 & 0 & 8 & 1 \\
\hline Pristina jenkinae (Stephenson, 1931) & 2 & 0 & 0 & 2 & 76 & 0 \\
\hline Pristina $\mathrm{sp} .1$ & 88 & 0 & 3 & 0 & 26 & 7 \\
\hline Pristina sp. 2 & 4 & 0 & 0 & 0 & 1 & 0 \\
\hline Pristina sp. 3 & 0 & 0 & 0 & 0 & 2 & 0 \\
\hline \multicolumn{7}{|l|}{ Tubificinae } \\
\hline Immature tubificines & 9 & 0 & 4 & 0 & 4 & 2 \\
\hline \multicolumn{7}{|l|}{ ENCHYTRAEIDAE } \\
\hline Achaeta sp. & 5 & 0 & 3 & 0 & 1 & 2 \\
\hline Other enchytraeids & 35 & 3 & 7 & 1 & 59 & 11 \\
\hline MEGADRILI & 1 & 0 & 0 & 0 & 0 & 0 \\
\hline Abundance & & 190 & & & 232 & \\
\hline Richness & & 10 & & & 14 & \\
\hline Shannon-Wiener diversity & & 0.963 & & & 1.087 & \\
\hline
\end{tabular}

show any effect of water velocity on the abundance and richness of oligochaetes, Habdija et al. (2004) showed that in bryophytes the abundance increased with faster water flow, indicating that this substrate provides refuge for fauna. An increase in abundance and richness in the rainy season has also been reported for other groups of macroinvertebrates in bryophyte habitats (Rosa et al. 2011, 2013).

Enchytraeidae represented $30 \%$ of the fauna collected. Percival \& Whitehead (1929) found that Enchytraeidae were frequent inhabitants of mosses in shallow areas of temperate streams. According to
Johnson \& Ladle (1989), probably the majority of records of Enchytraeidae in low-order streams are the result of accidental derivation from adjacent terrestrial populations, since these streams are very narrow and shallow, intensifying the interaction between the components of the water and land.

The Naididae family was the best represented, with 12 taxa. Most species of the subfamilies Naidinae and Pristininae are free swimmers (Verdonschot et al. 1982), allowing these invertebrates to colonize a variety of substrates in streams, including bryophytes. 

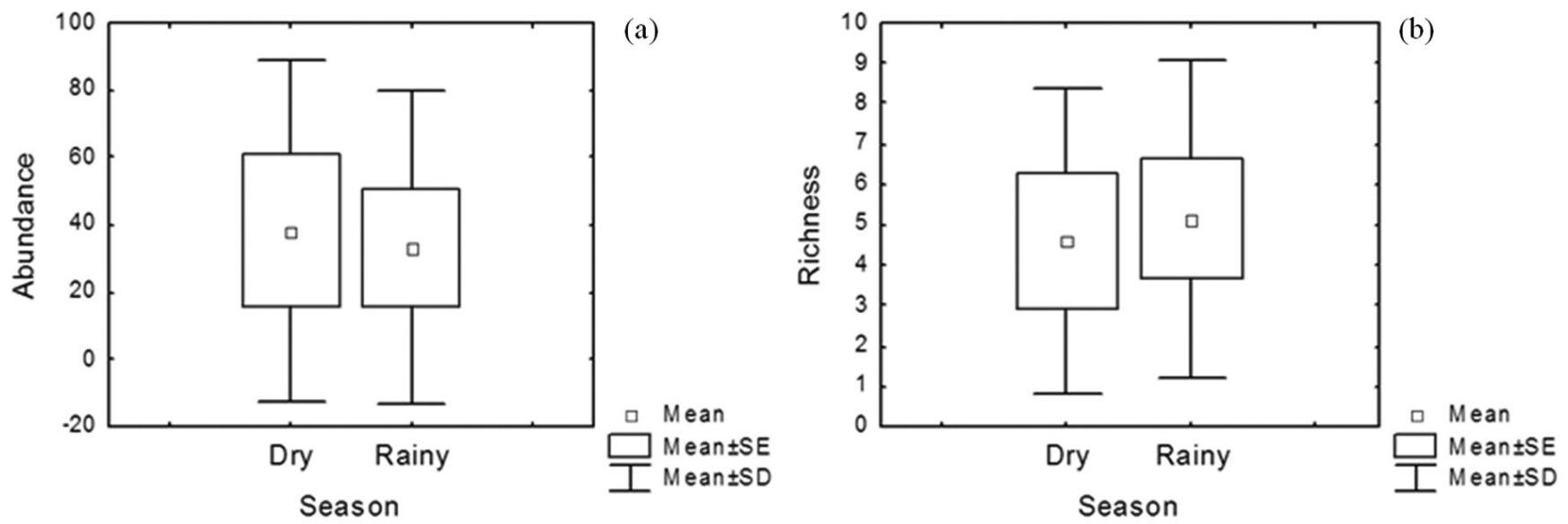

Figure 2. Abundance (a) and richness (b) of oligochaetes in the two collection periods.
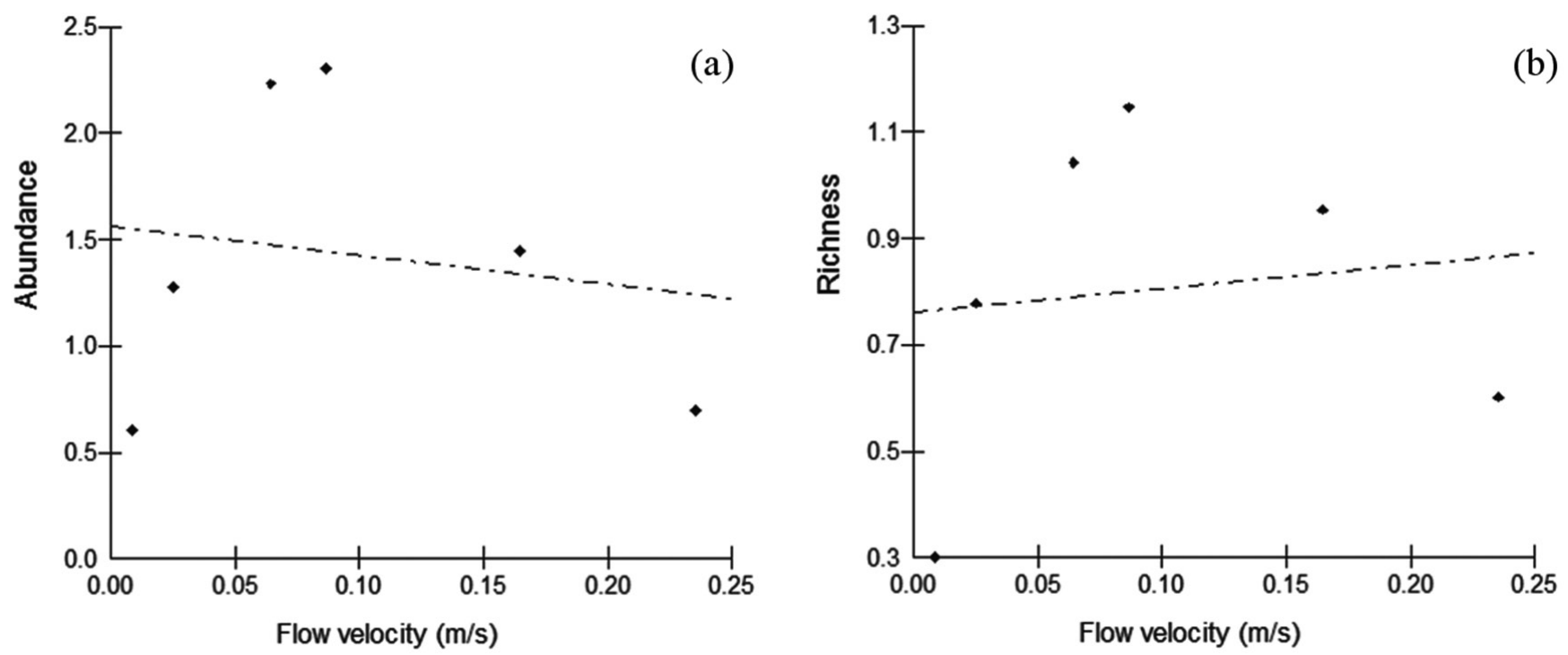

Figure 3. Effect of flow velocity on abundance (a) and richness (b) of oligochaetes associated with bryophytes in a first-order stream in the Poço D'Anta Municipal Biological Reserve, southeastern Brazil.

Baturina (2007) reported dominance of Naidinae and Pristininae (up to $70 \%$ of the oligochaetes) in bryophytes adhered to rocks in Russian streams. Naidinae and Pristininae also were the only subfamilies found by Gorni \& Alves (2007) in bryophytes collected on rocky substrates of riffles. $P$. jenkinae was the most abundant species in bryophytes collected by Gorni \& Alves (2007), who observed greatest abundance in the rainy season (spring). Parish (1981) observed that species such as $N$. communis and C. diastrophus presented peak abundance in the spring, while $P$. aequiseta, $P$. leidy $i$ and $P$. osborni presented peaks in the autumn. However, according to Smith (1986), there is no consensus on a single and constant time period or season when Naididae are most abundant. An explanation is that besides air temperature, which increases the metabolism and stimulates asexual reproduction, promoting peaks of abundance, the availability of food and other physical and chemical parameters, such as electrical conductivity, act together for population regulation of the Naididae, resulting in a wide range of conditions favorable to peaks of abundance. The relatively short observation period (six months) in the present study, although allowing the collection of information on the numerical abundance of the species found in the two collection periods, did not allow us to detect temporal variation patterns.
The results of this study indicate that the bryophytes are important substrates for oligochaetes, offering protection against natural hydrological disturbances. The results also indicate the importance of preserved streams for maintenance of the diversity and preservation of these invertebrates.

\section{Acknowledgments}

We thank the Minas Gerais State Research Support Foundation (FAPEMIG) for the research grant and the National Council for Scientific and Technological Development (CNPq) for ongoing support (process 303790/2009-1).

\section{References}

BATURINA, M. 2007. Oligochaeta of the Pechora River Basin, Russia. Acta Hydrobiol. Sinica 31(Suppl.):36-46.

BATURINA, M. 2012. Distribution and diversity of aquatic Oligochaeta in small streams of the middle taiga. Turk. J. Zool. 36(1):75-84.

BRINKHURST, R.O. \& MARCHESE, M.R. 1989. Guia para la indentificación de oligoquetos acuáticos continentales de Sud y Centroamérica. Clímax, Santa Fé. 
CARRERA, N., BARREAL, M. E., RODEIRO, J. \& BRIONES, M.J. I. 2011 Interactive effects of temperature, soil moisture and enchytraeid activities on C losses from a peatland soil. Pedobiologia 54(5-6):291-299. http:// dx.doi.org/10.1016/j.pedobi.2011.07.002

DÓZSA-FARKAS, K. 1990. New enchytraeid species from sphagnum-bogs in Hungary (Oligochaeta, Enchytraeidae). Acta Zool. Hungarica 36(34):265-274.

ERSÉUS, C., WETZEL, M.J. \& GUSTAVSSON, L. 2008. ICZN rules-a farewell to Tubificidae (Annelida, Clitellata). Zootaxa 1744(1):66-68.

GLIME, J.M. 2007. Bryophyte Ecology. Michigan Technological University, International Association of Bryologists. Volume 2 (Chapter 4). Physiological Ecology. http://www.bryoecol.mtu.edu/ (último acesso em 14/12/2012).

GORNI, G.R. \& ALVES, R.G. 2007. Naididae (Annelida, Oligochaeta) associated with bryophytes in Brotas, State of São Paulo, Brazil. Rev. Bras. Zool. 24(2):518-519. http://dx.doi.org/10.1590/S010181752007000200036

HABDIJA, I., PRIMC HABDIJA, B., MATONIČKIN, R., KUČINIC, M., RADANOVIC, I., MILIŠA, M. \& MIHALJEVIC, Z. 2004. Current velocity and food supply as factors affecting the composition of macroinvertebrates in bryophyte habitats in karst running water. Biol. Bratislava 59(5):577-593.

HEINO, J. \& KORSU, K. 2008. Testing species-stone area and speciesbryophyte cover relationships in riverine macroinvertebrates at small scales. Freshwater Biol. 53(3):558-568. http://dx.doi.org/10.1111/j.13652427.2007.01920.x

JOHNSON, P. \& LADLE, M. 1989. The Enchytraeidae (Oligochaeta) of streams of Southern England. An. Limnol. 25(2):121-129. http://dx.doi. org/10.1051/limn/1989012

KIKUCHI, R.M. \& UIEDA, V.S. 2005. Composição e distribuição dos macroinvertebrados em diferentes substratos de fundo de um riacho no município de Itatinga, São Paulo, Brasil. Entomol. Vect. 12(2):193-231. http://dx.doi.org/10.1590/S0328-03812005000200006

LINHART, J., VLČKOVÁ, Š. \& UVÍRA, V. 2002. Bryophytes as a special mesohabitat for meiofauna in a rip-rapped channel. River Res. Appls. 18(4):321-330. http://dx.doi.org/10.1002/rra.671

MARTINELLI, L.A. \& KRUSCHE, A.V. 2007. Amostragem em rios. In Amostragem em Limnologia (C.E.M. Bicudo \& D.C. Bicudo, org). 2nd ed. RiMa, São Carlos, p.263-279.

PARISH, J. 1981. Reproductive ecology of Naididae (Oligochaeta) Hydrobiologia 83(1):115-123. http://dx.doi.org/10.1007/BF02187156
PERCIVAL, E. \& WHITEHEAD, H. 1929. A quantitative study of the fauna of some types of stream-bed. J. Ecol. 17(2):282-314. http://dx.doi. org/10.2307/2256044

R DEVELOPMENT CORE TEAM. 2011. R: A language and environment for statistical computing. R Foundation for Statistical Computing, Vienna. http://www.R-project.org/.

RIGHI, G. 1984. Manual de identificação de invertebrados límnicos do Brasil. $\mathrm{CNPq}$, Coordenação Editorial, Brasília.

ROSA, B.F.J.V., SILVA, M.V.D., OLIVEIRA, V.C., MARTINS, R.T. \& ALVES, R.G. 2011. Macroinvertebrates associated with bryophyta in a first-order Atlantic Forest stream. Rev. Bras. Zool. 28(3):351-356.

ROSA, B.F.J.V., SILVA, M.V.D. \& ALVES, R.G. 2013. Composition and structure of the Chironomidae (Insecta: Diptera) community associated with bryophytes in a first-order stream in the Atlantic Forest, Brazil. Neotrop. Entom. 42(1):15-21. PMid:23949708. http://dx.doi.org/10.1007/ s13744-012-0086-0

SILVEIRA, M.P., BUSS, D.F., NESSIMIAN, J.L. \& BAPTISTA, D.F. 2006. Spatial and temporal distribution of benthic macroinvertebrates in a southeastern Brazilian river. Braz. J. Biol. 66(2b):623-632. PMid:16906294. http://dx.doi.org/10.1590/S1519-69842006000400006

SMITH, M. E. 1986. Ecology of Naididae (Oligochaeta) from an alkaline bog steam: life history patterns and community structure. Hydrobiologia 133(1):79-90. http://dx.doi.org/10.1007/BF00010805

STANDEN, V. \& LATTER, P.M. 1977. Distribution of a population of Cognettia sphagnetorum (Enchytraeidae) in relation to microhabitats in a Blanket Bog. J. Anim. Ecol. 46(1):213-229. http://dx.doi. org $/ 10.2307 / 3957$

STATSOFT. STATISTICA (data analysis software system). 2004. version 7. ww.statsoft.com.

SUREN, A.M. 1992. Meiofaunal communities associated with bryophytes and gravels in shaded and unshaded alpine streams in New Zealand, New. Zeal. J. Mar. Fresh. 26(1):115-125.

SUREN, A.M. \& WINTERBOURN, M.J. 1992. The influence of periphyton, detritus and shelter on invertebrate colonization of aquatic bryophytes. Freshwater. Biol. 27(3):327-339. http://dx.doi.org/10.1080/00288330. 1992.9516507

VERDONSCHOT, P.F.M., SMIES, M. \& SEPERS, A.B.J. 1982. The distribution of aquatic oligochaetes in brackish inland waters in the SW Netherlands. Hydrobiologia 89(1):29-38. http://dx.doi.org/10.1007/ $\mathrm{BF} 00017535$

VLČKOVÁ, S., LINHART, J. \& UVÍRA, V. 2002. Permanent and temporary meiofauna of an aquatic moss Fontinalis antipyretica. Hedw. Acta U. Palack. Olom. 39-40(1):131-140. 